\title{
Contribution of Discipline to Forming Employee Perfomance at the Community Health Center (Puskesmas) of Raya Pematangsiantar City
}

\author{
Vivi Candra \\ Sekolah Tinggi Ilmu Ekonomi Sultan Agung \\ vivicandra018@gmail.com
}

\section{Sherly}

Sekolah Tinggi Ilmu Ekonomi Sultan Agung sherly@stiesultanagung.ac.id

\section{Edy Dharma}

Sekolah Tinggi Ilmu Ekonomi Sultan Agung edydharma@stiesultanagung.ac.id

\begin{abstract}
Abstrak This study aims to determine the effect of discipline on the performance of employees of the Community Health Center (Puskesmas) of Raya Pematangsiantar City. This research used the design of literature and field research. The research method used was the causality method with a quantitative approach. The type of data used in this study was qualitative and quantitative data. Data sources consisted of primary and secondary data. The population and sample used in this study were 34 permanent employees. Data collection was done by questionnaire, interview, and documentation. The analysis technique used was qualitative descriptive and quantitative descriptive analysis consisting of multiple linear regression, correlation test, the test of determination and hypothesis. The results of this study concluded that employee discipline and performance was good. Regarding the results of the hypothesis, it shows that discipline has a positive and significant effect on employee performance.
\end{abstract}

Kata Kunci Discipline, Employee Perfomance, Puskemas Raya

\section{INTRODUCTION}

The success of an organization's purpose depends on the labor employed. The organization is a social unit that is coordinated consciously with a clear boundary in the organization (Astutik, 2016). Companies and organizations are categorized as good when they have quality human resource assets and carry out work optimally so that the target of the companies and organizations can be achieved (Sahir et al., 2020). Performance in organizations is very crucial to improve the effectiveness of organizational performance to achieve organizational goals that have been set (Sutrisno, 2013). Therefore, aspects of human resources are required to support the achievement of the effectiveness of the 
intended organizational performance. Human resources or labor is required both in government agencies, social enterprises, and companies. Basically, the wider community measures the success of an organization based on the ability seen from the performance.

Discipline is an attitude of respect, appreciation, obedience and compliance with applicable regulations. Moreover, according to Rivai (2009), "discipline is a tool used by managers to communicate with employees so that they are willing to change behavior and as an effort to increase one's awareness and willingness to meet all company regulations." An article discussing discipline written by (Klein, 2005) defined that it as a matter rooted in the commitment of every member of the organization in carrying out each task in the right and proper way. Discipline at the Community Health Center (Puskesmas) of Raya is still not optimal. It can be seen from the dimensions in carrying out its obligations that some employees still violate regulations repeatedly, especially in utilizing work time such as leaving during working hours without notice and being late coming to the health center, and not present without clear information.

\section{LITERATUR REVIEW}

\subsection{Discipline}

Work discipline is one of the representative forms of performance that meets the elements of professionalism as an employee and staff. Therefore, work discipline is needed to improve to form an individual professional level (Wariati, Dahniar and Sugiati, 2015). Implementation of discipline aims to improve and shape employee knowledge, attitudes, and behavior so that it impacts on the quality of work and communication with fellow employees (Soegoto and Salutondok, 2015). The application of the disciplinary dimension of the Community Health Center (Puskesmas) of Raya Pematangsiantar City based on government regulation number 53 of 2010 concerning civil servants has obligations that must be carried out and restrictions that must be avoided to realize good discipline. Good employee discipline will increase employee performance and, vice versa, bad discipline will reduce their performance. If discipline is not enforced, employees will have no responsibility for the organization.

\subsection{Employee Perfomance}

Improving employee performance is not a simple thing to do and achieve by an organization (Istiqomah and Suhartini, 2016). Good performance is an optimal performance by meeting the rules and standards of the organization (Ayer, Pangemanan and Rori, 2016). The employee performance of Community Health Center (Puskesmas) of Raya Pematangsiantar City is measured by a dimension based on Employee Performance Targets (SKP) consisting of quantity, quality, time, and cost. Meanwhile, performance behavior (PK) consists of servant orientation, integrity, commitment, discipline, cooperation, and leadership. The phenomenon of employee performance based on Employee Performance Targets (SKP) is due to the fact that not all employees can do their jobs quickly or on time as the length of the patient data queue. For performance behavior (PK), regarding service orientation,some employees are not good enough in providing services to the community such as employees who are less alert, delay in providing services, and sell personal items in the office environment for personal gain. Therefore, it highly interferes with service in Puskesmas which ultimately impacts 
employee performance. Improving employee performance can be carried out in many ways; one of them is by applying discipline to the employees (Ardi and Sukmasari, 2016).

\section{RESEARCH METHOD}

In this study, the authors used literature and field research designs. The research method used was the causality method with a quantitative approach. The research object was the employee of Community Health Center (Puskesmas) of Raya Pematangsiantar City. The type of data used was qualitative and quantitative data. Source of data came from primary and secondary data. Research data were collected by conducting interviews, documentation, and distributing questionnaires. Data analysis included qualitative and quantitative data analysis. Quantitative analysis included simple linear regression analysis, correlation, and coefficient of determination and hypothesis testing with the partial test ( $t$-test).

\section{RESULT}

\subsection{Depiction of Discipline at Community Health Center (Puskesmas) of Raya Pematangsiantar City}

Overall employee discipline has an average value of 3.55 with good answer criteria. The highest average value of discipline is 3.74 with good answer criteria in the dimension away from the prohibition with the indicator not taking action that can complicate the party being served. The lowest average discipline value of 2.85 with the criteria of the answer is good enough on the dimensions of carrying out the obligation with indicators to obey the provisions of working hours.

\subsection{Depiction of Employee Performance at Community Health Center (Puskesmas) of Raya Pematangsiantar City \\ Overall, it can be seen that the employee performance of Community Health} Center (Puskesmas) of Raya Pematangsiantar City based on the dimensions of work targets and work behavior are at an average value of 3.57 with good response criteria. The highest average value is in the dimensions of work targets for indicators of the level of achievement of work targets of 3.71 with good answer criteria. The lowest average value of employee performance is in the dimensions of employee work behavior for the level indicator.

\subsection{Quantitative Descriptive Analysis}

\subsubsection{Simple Linear Regression Analysis}

It is used to analyze the effect of discipline $\left(\mathrm{X}_{1}\right)$ on employee performance $(\mathrm{Y})$ at the Community Health Center (Puskesmas) of Raya Pematangsiantar City. The calculation of data analysis used SPSS version 21, obtaining regression results as follows:

Table 1

Simple Linear Regression Results

\begin{tabular}{|l|l|l|}
\hline Model & Unstandardized Coefficients & Standardized Coefficients \\
\cline { 2 - 3 }
\end{tabular}




\begin{tabular}{|l|r|r|rr|}
\hline & \multicolumn{1}{|c|}{ B } & \multicolumn{1}{|c|}{ Std. Error } & \multicolumn{2}{|c|}{ Beta } \\
\hline 1 (Constant) & 11.059 & 8.839 & & \\
Discipline &, 523 &, 075 & &, 777
\end{tabular}

a. Dependent Variable Employee Performance

Source: SPSS Statistics version 21 (2019)

The results of regression with SPSS version 21 in table 1 above obtained a regression coefficient of $b_{1}$ of 0.523 so that it can be seen that the regression equation obtained is $\hat{Y}$ $=11,059+0,523 \mathrm{X}_{1}$, indicating thatthere is a positive effect between discipline on employee performance at the Community Health Center (Puskesmas) of Raya Pematangsiantar City.

\subsubsection{Correlation Analysis and Coefficient of Determination}

To determine the strength of the relationship of discipline to employee performance, a correlation analysis in the form of the degree or depth of the functional relationship is carried out which explains the relationship between $r$ values. The $r$ values can be seen in the following table:

Table 2

Correlation Coefficient and Coefficient of Determination

\begin{tabular}{|l|r|r|r|r|}
\hline Model & \multicolumn{1}{|c|}{$\mathrm{R}$} & R Square & Adjusted R Square & Std. Error of the Estimate \\
\hline 1 & $.777^{\mathrm{a}}$ & .604 & .591 & 4.921 \\
\hline
\end{tabular}

a. Predictors: (Constant), Discipline

b. Dependent Variable: Employee Performance

Source: SPSS Statistics version 21 (2019)

The results of the regression analysis with SPSS in table 2 above obtained a correlation of $r=0.777$, indicating that there is a strong and positive relationship between discipline and employee performance at the Community Health Center (Puskesmas) of Raya Pematangsiantar City. The coefficient of determination is 0.604 , indicating that good or bad employee performance can be explained by $60.4 \%$ by work discipline and the rest of $39.6 \%$ is explained by other factors such as the work environment, communication, compensation, and so on.

\subsubsection{Hypothesis testing}

The next test is the $t$-test. This test is performed partially to determine whether the hypothesis is accepted or rejected. The effect of the hypothesis is carried out to determine whether the variable of discipline tested affects employee performance. Ift $t_{\text {count }}>t_{\text {tableif }}$ significant $\alpha \leq 0,05$ then $\mathrm{H}_{0}$ is rejected. To test the validity, hypothesis testing was performed using SPSS version 21.

Table 3

The estimated value of $t_{\text {count }}$

\begin{tabular}{|c|c|c|}
\hline Model & $\mathrm{t}$ & Sig \\
\hline
\end{tabular}




\begin{tabular}{|c|c|c|}
\hline Constant & 1.251 & 0.220 \\
\hline Work Discipline & 6.980 & 0.000 \\
\hline
\end{tabular}

Source: SPSS Statistics version 21 (2019)

Based on table 3 above, $t_{\text {count }}$ can be seen in the variable of discipline $\left(\mathrm{X}_{1}\right)$ of $6,980>\mathrm{t}_{\text {tablewithdf }}=\mathrm{n}-\mathrm{k}-1(34-2-1)$ indicating 2,039 or level of significance of $0,001 \leq$ $\alpha 0,05$ then $\mathrm{H}_{0}$ is rejected. It indicates that discipline has a positive and significant effect on employee performance at the Community Health Center (Puskesmas) of Raya Pematangsiantar City.

\subsection{Effect of Discipline on Employee Performance}

A social force that is invisible and at the same time can move people in an organization to perform work activities is representative of the strengths and weaknesses of the influence of organizational culture on a company or organization is called discipline. Based on the results of the study above, it is known that discipline affects employee performance at the Community Health Center (Puskesmas) of Raya Pematangsiantar City. These results are in line with the research conducted by (Juhana and Haryati, 2013), (Jannah, Fitria and Hadiat, 2014), (Irawan and Suryani, 2018), (Isvandiari and Idris, 2018), (Lie et al., 2019), (Syamsuri, 2014), (Syaleh, 2017), who stated that discipline has a significant effect on performance.

\section{CONCLUSION}

The results of simple linear regression analysis show that discipline has a positive and significant effect on employee performanceat the Community Health Center (Puskesmas) of Raya Pematangsiantar City. The results of the correlation analysis show that there is a strong and positive relationship between discipline and employee performance at the Community Health Center (Puskesmas) of Raya Pematangsiantar City. Then, the analysis of the coefficient of determination shows that the high and low performance of employees in the Community Health Center (Puskesmas) of Raya Pematangsiantar City can be explained, one of which is by one's level of discipline. The results of hypothesis testing with $t$-test (partial test) obtained that $\mathrm{H}_{0}$ is rejected, indicating that there is a positive and significant effect of discipline on employee performance at Community Health Center (Puskesmas) of Raya Pematangsiantar City. To improve discipline at the Community Health Center (Puskesmas) of Raya Pematangsiantar City, it is better to increase the initiative of employees to be on time such as arriving at the office five minutes before morning rally and notifying picket officers about matters outside the office if one cannot return on time to the office after recess. Also, enactment of strict sanctions for employees who violate rules in the form of verbal and written reprimands (warning letters). Furthermore, to manage and improve employee performance at the Community Health Center (Puskesmas) of Raya Pematangsiantar City which is not yet optimal, it is suggested for the supervisors to give trust to senior employees who are eager to work to guide employees who are slow in providing services. Also, the employees should improve professional attitude at work.

\section{REFERENCES}


Ardi, R. P. and Sukmasari, N. (2016) 'Pengaruh Disiplin Kerja, Promosi Jabatan dan Kompensasi Terhadap Kinerja Pegawai pada Dinas Kebudayaan Pariwisata Pemuda dan Olahraga Kabupaten Rembang', Ebbank, 7(2), pp. 105-110. Available at: http://ebbank.stiebbank.ac.id/index.php/EBBANK/article/view/98.

Astutik, M. (2016) 'Pengaruh Disiplin Kerja dan Budaya Organsisasi Terhadap Kinerja Pegawai Sekretariat Dewan Perwakilan Rakyat Daerah Kabupaten Jombang', JBMP (Jurnal Bisnis, Manajemen dan Perbankan), 2(2), pp. 121-140. doi: 10.21070/jbmp.v2i2.1098.

Ayer, J. E., Pangemanan, L. R. J. and Rori, Y. P. I. (2016) 'Pengaruh Motivasi Dan Disiplin Kerja Terhadap Kinerjapegawai Pada Dinas Pertanian Kabupaten Supiori', Agri-Sosioekonomi, 12(3A), pp. 27-46. doi: 10.35791/agrsosek.12.3a.2016.14285.

Irawan, A. and Suryani, N. (2018) 'Pengaruh Gaya Kepemimpinan, Fasilitas Kantor, Dan Disiplin Kerja Terhadap Kinerja Pegawai Dinas Perdagangan Kota Semarang, Economic Education Analysis Journal, 7(1), pp. 265-278.

Istiqomah, S. N. and Suhartini, S. (2016) 'Pengaruh disiplin kerja dan iklim komunikasi terhadap kinerja pegawai Dinas Perhubungan Kota Yogyakarta, dengan motivasi kerja sebagai variabel intervening', Jurnal Siasat Bisnis. doi: 10.20885/jsb.vol19.iss1.art8.

Isvandiari, A. and Idris, B. Al (2018) 'Pengaruh Kepemimpinan Dan Disiplin Kerja Terhadap Kinerja Karyawan Pada Pt Central Capital Futures Cabang Malang, Jurnal Ilmiah Bisnis dan Ekonomi Asia, 12(1), pp. 17-22. doi: 10.32812/jibeka.v12i1.7.

Jannah, A., Fitria, B. T. and Hadiat, E. (2014) 'Pengaruh Kompensasi, Pengembangan Karier, dan Disiplin Kerja Terhadap Kinerja Pegawai Dinas Pendapatan Daerah Kota Cimahi', Jurnal Ekonomi, Bisnis dan Enterpreneurship, 8(2), pp. 99-110.

Juhana, D. and Haryati (2013) 'Pengaruh Motivasi, Disiplin Dan Lingkungan Kerja Terhadap Kinerja Pegawai Pada Dinas Kesehatan Kota Cimahi', Jurnal Ekonomi, Bisnis \& Entrepreneurship, 7(2), pp. 84-94. Available at: http://jurnal.stiepas.ac.id/index.php/jebe/article/view/32.

Klein, J.A., Bradshaw, W.M., VandenHeuvel, L.N., Lorenzo, D.K., Keeports, G., 2011. Implementing an effective conduct of operations and operational discipline program. J. Loss Prev. Process Ind. 24, 98-104. http://dx.doi.org/10.1016/j.jlp.2010.10.003.

Lie, D. et al. (2019) 'The Impact of Work Discipline and Work Ethic on the Teacher Performance of Sultan Agung Pematangsiantar Private Middle School Teachers T.A. 2018/2019', International Journal of Business Studies, 3(3), pp. 125-135. doi: 10.32924/ijbs.v3i3.83.

Rivai, Viethzal, 2009. Manajemen Sumber Daya ManusiaUntuk Perusahaan. Edisi III. Jakarta: Raja Grafindo persada.

Sahir, S. H. et al. (2020). Keterampilan Manajerial Efektif. Cetakan 1. Medan: Yayasan Kita Menulis.

Soegoto, A. and Salutondok, Y. (2015) 'Pengaruh Kepemimpinan, Motivasi, Kondisi Kerja Dan Disiplin Terhadap Kinerja Pegawai Di Kantor Sekretariat Dprd Kota Sorong', Jurnal Riset Ekonomi, Manajemen, Bisnis dan Akuntansi, 3(3), pp. 849862. 
Sutrisno, S. (2013) 'Pengaruh Disiplin Kerja Dan Motivasi Kerja Terhadap Kinerja Pegawai Negeri Sipil ( Studi Di Kantor Dinas Sosial Provinsi Jawa Tengah )', Jurnal Ilmiah Dinamika Ekonomi Dan Bisnis, 1(1), pp. 1-15.

Syaleh, H. (2017) 'Pengaruh Diklat Dan Disiplin Kerja Terhadap Kinerja Pegawai Dinas Pendapatan Pengelolaan Keuangan Dan Asset Daerah Kabupaten Lima Puluh Kota', Jurnal Benefita, 2(3), pp. 208-219. doi: 10.22216/jbe.v2i3.1632.

Syamsuri, A. R. (2014) 'Analisis Pengaruh Pendidikan, Pengawasan Kerja dan Disiplin Terhadap Kinerja Pegawai Dinas Pendidikan Kabupaten Mandailing Natal', Jurnal Ecobisma, 1(1), pp. 44-55.

Wariati, N., Dahniar and Sugiati, T. (2015) 'Pengaruh Disiplin Kerja dan Pengalaman Kerja Terhadap Kinerja Pegawai Dinas Pendapatan Pengelolaan Keuangan dan Aset Kabupaten Barito Timur', Wawasan Manajemen, 3(3), pp. 217-228. 